\title{
Involvement of Oxidative Stress in Bactericidal Activity of Vanillic Acid Against Staphylococcus aureus
}

\author{
'Sulaimon Olayiwola Folami ${ }^{2}$ Quadri Olaide Nurudeen ${ }^{3}$ Mansurat Bolanle Falana \\ ${ }^{2}$ Taofeek Olakunle Ajiboye and ${ }^{4}$ Adamu Jibril Bamaiyi \\ ${ }^{1}$ Department of Biochemistry, Kebbi State University of Science and Technology, Aliero, Kebbi State, Nigeria \\ 2Department of Biological Sciences (Biochemistry Unit), Al-Hikmah University, Ilorin, Nigeria \\ ${ }^{3}$ Department of Biological Sciences (Microbiology Unit), Al-Hikmah University, Ilorin, Nigeria \\ ${ }^{4}$ Department of Physiology, Faculty of Basic Medical Sciences, College of Health Sciences, Usmanu Danfodiyo University, Sokoto, Nigeria.
}

\begin{abstract}
Background: There is emerging interest in the potential of vanillic acid to induce oxidative stress. Hence, this study evaluated the involvement of oxidative stress in bactericidal activity of vanillic acid.

Materials and Methods: The antibacterial activities of vanillic acid against Staphylococcus aureus was tested at different concentrations $(10 \mathrm{ng} / \mathrm{mL}$, $100 \mathrm{ng} / \mathrm{mL}, 1 \mu \mathrm{g} / \mathrm{mL}, 10 \mu \mathrm{g} / \mathrm{mL}, 100 \mu \mathrm{g} / \mathrm{mL}$ and $0.1 \mathrm{mg} / \mathrm{mL}$ ) by microdilution susceptibility method. The results were compared with DMSO (negative control) and ciprofloxacin (positive control). Six groups were treated thus; group 1 contained $4.5 \mathrm{~mL}$ broth with $0.5 \mathrm{~mL}$ DMSO (serving as control) and $S$. aureus, group 2 contained $4.5 \mathrm{~mL}$ broth with 0.5 $\mathrm{mL}$ 2'2-bipyridyl and S. aureus, group 3 contained $4.5 \mathrm{~mL}$ broth with $0.5 \mathrm{~mL}$ thiourea and $S$. aureus, group 4 contained $4.5 \mathrm{~mL}$ broth with $0.5 \mathrm{~mL}$ Vanillic acid prepared in DMSO and S. aureus, group 5 contained $4.4 \mathrm{~mL}$ broth with $0.5 \mathrm{~mL}$ Vanillic acid, $0.1 \mathrm{~mL}$ 2'2-bipyridyl inoculated and $S$. aureus while group 6 contained $4.4 \mathrm{~mL}$ broth with $0.5 \mathrm{~mL}$ Vanillic acid, $0.1 \mathrm{~mL}$ thiourea. Various subsections of group 4 were prepared for all concentrations. All the treatments were incubated at $37^{\circ} \mathrm{C}$ for $3 \mathrm{~h}$ and the absorbance was monitored as a measure of cell concentration at $600 \mathrm{~nm}$ every 30 mins over the 3 -h incubation period.
\end{abstract}

Results: A time- dependent decrease in the cells of $S$. aureus following exposure to vanillic acid was observed when compared with DMSO but slightly increased when compared with ciprofloxacin. Similar dose dependent increase in the activity of superoxide dismutase and catalase were recorded. The non-enzymatic antioxidant, glutathione, decreased significantly $(\mathrm{p}<0.05)$, while the level of malondialdehyde and fragmented DNA increased significantly $(\mathrm{p}<0.05)$.

Corresponding Author

Quadri Olaide Nurudeen, Ph.D. Department of Biological Sciences, Al-Hikmah University, Ilorin, Nigeria.

Tel: +234-803-4273-045,

E-mail: quadriolaide@yahoo.com
Conclusions: This study showed an induced oxidative stress in Staphylococcus aureus following exposure to vanillic acid.

Keywords: 2,2 bipyridyl; dimethyl sulfoxide (DMSO); Oxidative stress, Staphylococcus aureus Vanillic acid

\section{Introduction}

Vanillic acid, one of the major phenolic derivatives from edible plants and fruits belongs to the class of the benzoic acid derivatives (1). Phenolics are also important components of the human diet due to their potential antioxidant activity (2), their capacity to diminish oxidative stress induced tissue damage resulting from chronic diseases (3) and their potentially important properties such as anticancer activities. The structure of phenolics consists of an aromatic ring carrying one (phenol) or more hydroxyl (polyphenol) moieties. Several classes can be distinguished according to the number of phenol rings and to the structural elements that join these rings $(4,5)$. Two classes of phenolic acids can be distinguished depending on their structure: benzoic acid derivatives (i.e. hydroxybenzoic acids, C6-C1) and cinnamic acid derivatives (i.e. hydroxycinnamic acids, C6-C3) (6).

Vanillic acid (4-hydroxy-3-methoxybenzoic acid) occurs in many plants such as prickly ash (Fagara spp.), 
Japanese alder (Alnus japonica), spiny oleaster (Elaeagnus pungens), Spanish heath (Erica australis), upland cotton (Gossypium mexicanum), Chinaberry (Melia azedarach), oriental ginseng (Panax ginseng), Korean peroba (Parateco makoraiensis), red sandalwood (Pterocarpus santalinus), dog rose (Rosa canina), shensi (Picrorhiza kurrooa), luoshi (Trachelospermum asiaticum), ishpingo (Amburanace arensis), and Shiitake mushroom (Lentinul aedodes). Besides anti-sickling and antihelmintic activities, vanillic acid could suppress hepatic fibrosis in chronic liver injury (1). It is also found to be an inhibitor of snake venom 5'-nucleotidase (7). Mol and Raja (8) have shown the potential protective role of vanillic acid against the acetaminophen, which is a widely used analgesic and antipyretic drug and in overdose can cause lifethreatening hepatotoxicity and nephrotoxicity in humans (8).

Escherichia coli, Pseudomonas aeruginosa and Staphylococcus aureus are medically important organisms that infect plants, animals and humans. However, resistance by these pathogens to most of the commonly employed antibiotics may be due to wide range of biochemical and physiological mechanisms. Over the last decade, intense investigation revealed that oxidative stress is involved in lethality of antibiotics with different mechanisms of action. Research is therefore required to know the various concentrations in which they inhibit the growth of the following organisms. The success of this work will obviously enhance studies on the production of antibiotics producing strains of different microbes and obviously the production of antibiotics on a larger scale.

\section{MATERIALS AND METHODS}

\section{Collection of Bacteria strain}

Staphylococcus aureus ATCC 29213 used in this study was obtained from the Microbiology Laboratory of University of Ilorin Teaching Hospital and maintained on Nutrient agar slant.

\section{Reagents and materials}

All the reagents used in this study were of analytical grade. Vanillic acid is a product of Santa Cruz Biotechnology (Dallas, TX, USA) while Nitroblue tetrazolium, sodium chloride, peptone water, epinephrine,5,5'-dithiobis-2-nitrobenzoic acid (DTNB) trichloroacetic acid (TCA), hydrogen peroxide $\left(\mathrm{H}_{2} \mathrm{O}_{2}\right)$, 2'2-bipyridyl were purchased from Sigma-Aldrich (St. Louis, MO, USA).

\section{Ethical guidelines}

An ethical approval was granted by the Ethical Review Committee of the Al-Hikmah University, Ilorin, Nigeria in accordance with institutional guidelines.

\section{Susceptibility testing of Staphylococcus aureus ATCC 29213 to vanillic acid}

The susceptibility of Staphylococcus aureus ATCC 29213 to vanillic acid was investigated in a 96-well microtitre plates using the procedure described by Samoilova et al. (9) as modified by Ajiboye et al. (10). S. aureus ATCC 29213 was grown overnight in Luria Bertani broth (LB), harvested by centrifugation and resuspended in $50 \mathrm{~mL}$ fresh medium (LB) and grown aerobically at $37^{\circ} \mathrm{C}$ in $250 \mathrm{~mL}$ flask, fresher medium was used to dilute the existing one. Vanillic acid prepared in dimethyl sulfoxide (DMSO) was added to obtain various concentrations $(10 \mathrm{ng} / \mathrm{mL}, 100 \mathrm{ng} / \mathrm{mL}, 1 \mu \mathrm{g} / \mathrm{mL}, 10 \mu \mathrm{g} /$ $\mathrm{mL}, 100 \mu \mathrm{g} / \mathrm{mL}$ and $0.1 \mathrm{mg} / \mathrm{mL}$ ) and incubated at $37^{\circ} \mathrm{C}$ for 3 hours. Absorbance of the incubation medium was read at $600 \mathrm{~nm}$ for every 30 minutes interval over 3 hours incubation time and recorded as a measure of cell concentration, indirectly representing the colony forming unit (CFU).

\section{Grouping of Broth Containing Microorganisms for Different Treatments}

The treatment groups were designated into six microbial growth groups 1- 6 and treated as follows:

Group 1, containing $4.5 \mathrm{~mL}$ Broth inoculated with $S$. aureus and $0.5 \mathrm{mLDMSO}$ (serving as control)

Group 2, containing $4.5 \mathrm{~mL}$ Broth inoculated with $S$. aureus and $0.5 \mathrm{~mL} 2$ '2-bipyridyl

Group 3, containing $4.5 \mathrm{~mL}$ Broth inoculated with $S$. aureus and $0.5 \mathrm{~mL}$ thiourea

Group 4, containing $4.5 \mathrm{~mL}$ Broth inoculated with $S$. aureus and $0.5 \mathrm{~mL}$ Vanillic acid $(100 \mathrm{mg} / \mathrm{mL})$ prepared in DMSO

Group 5, containing $4.4 \mathrm{~mL}$ Broth inoculated with $S$. aureus, $0.5 \mathrm{~mL}$ Vanillic acid and $0.1 \mathrm{~mL} 2 ' 2$ bipyridyl while

Group 6, containing $4.4 \mathrm{~mL}$ Broth inoculated with $S$. aureus, $0.5 \mathrm{~mL}$ Vanillic acid and $0.1 \mathrm{~mL}$ thiourea. 
Furthermore, all the treated groups were incubated at $37^{\circ} \mathrm{C}$ for 3 hours

\section{Preparation of cell free extract}

Cell free extract was prepared from the samples obtained after 3 hours incubation of Staphylococcus aureus ATCC 29213 with vanillic acid $(100 \mathrm{mg} / \mathrm{mL})$. Cells were harvested by centrifugation at $5000 \mathrm{~g}$ for 10 minutes, the pellets were suspended in sucrose solution $(0.25 \mathrm{M})$, vortexed, and the bacterial suspension was transferred into Eppendorf tubes placed on ice cubes. Glass beads (2g) were added to the bacterial suspension, homogenized using vortex mixer and centrifuged at 5000 $\mathrm{g}$ for 5 minutes at $4{ }^{0} \mathrm{C}$ to obtain the cell free extract as supernatant.

\section{Enzymatic biomarker}

\section{Superoxide Dismutase (SOD)}

The activity of superoxide dismutase was determined according to Misra and Fridovich (11). An indirect method of inhibiting auto oxidation of epinephrine to its adrenochrome was used to assay SOD activities. Superoxide dismutase activity was measured as the inhibition of the rate of reduction of cytochrome (by superoxide radical observed at $480 \mathrm{~nm}$ ). Cell free extract $(100 \mu \mathrm{L})$ was added to $125 \mu \mathrm{L}$ of $0.05 \mathrm{~mol} / \mathrm{L}$ carbonate buffer $(\mathrm{pH}$ 10.2) to equilibrate and the reaction was stopped by addition of freshly prepared $0.3 \mathrm{mmol} / \mathrm{L}$ epinephrine. The increase in absorbance at $480 \mathrm{~nm}$ was recorded every $30 \mathrm{~s}$ for $150 \mathrm{~s}$.

\section{Superoxide anion radical assay}

The level of superoxide anion radical in the cell free extract was determined using the procedure described by Ajiboye et al. (10). Cell free extract $20 \mu \mathrm{L}$ was incubated with $100 \mu \mathrm{L}$ nitroblue tetrazolium, NBT ( $1 \mathrm{mg} / \mathrm{mL})$ for $30 \mathrm{~min}$ at $37^{\circ} \mathrm{C}$. Then $20 \mu \mathrm{L}$ of $0.1 \mathrm{M} \mathrm{HCl}$ was added. The blank was reconstituted the same way except that the cell free extract was replaced with $0.25 \mathrm{M}$ sucrose solution. The blue colour was read at $575 \mathrm{~nm}$.

\section{Catalase}

Catalase activity was determined as described by Trombino et al. (12). Cell free extract $(10 \mu \mathrm{L})$ was added to $100 \mu \mathrm{L}$ cold $6 \mathrm{mM} \mathrm{H}_{2} \mathrm{O}_{2}$ and mixed thoroughly. After 3 minutes, the reaction was stopped by addition of $20 \mu \mathrm{L} 3$ $\mathrm{M} \mathrm{H}_{2} \mathrm{SO}_{4}$ and $140 \mu \mathrm{L} \mathrm{KMnO}_{4}$. The micro titre plate was shaken for thorough mixing and absorbance was read at $480 \mathrm{~nm}$ within $30-60$ seconds.

\section{Non-enzymatic biomarkers}

\section{Glutathione reduced assay}

The level of reduced glutathione in the cell free extract was determined according to the procedure described by Ellman (13). Reduced glutathione (GSH) was measured by its reaction with DTNB (5, 5'-dithiobis-2-nitrobenzoic acid) (Ellman's reaction) to give a yellow coloured product that absorbs light at $412 \mathrm{~nm}$. Cell free extract (20 $\mu \mathrm{L}$ ) was added to $170 \mu \mathrm{L} 0.1 \mathrm{M}$ potassium phosphate buffer ( $\mathrm{pH}$ 7.4). The reaction was initiated by adding 10 $\mu \mathrm{L}$ of $10 \mathrm{mM}$ 5'5- dithiobis (2-nitrobenzoic acid), DTNB. The mixture was incubated for 30 minutes at room temperature and the absorbance was read at $412 \mathrm{~nm}$. Standard GSH with $(0,20,40,60,80$ and $100 \mu \mathrm{M})$ were prepared and the absorbance was read.

\section{Quantification of Malondialdehyde}

The concentration of MDA was quantified according to the procedure described by Reilly and Aust (14). This was done following the reaction with Thiobarbituric acid (TBA) and measurement of the pink chromophore produced. Cell free extract $(50 \mu \mathrm{L})$ was added to mixture of thiobarbituric acid, $\mathrm{HCl}$ and Trichloroacetic acid (100 $\mu \mathrm{L})$. The mixture was boiled for 15 minutes on water bath, then, it was allowed to cool at room temperature. Absorbance was read at $535 \mathrm{~nm}$.

\section{Statistical analysis}

Results were expressed as mean of three independent experiments \pm standard error of mean. One way analysis of variance (ANOVA) followed by Student's $t$-test was used to detect any significant difference $(p<0.05)$ between the treatments.

\section{RESULTS}

The absorbance of Staphylococcus aureus following exposure to various concentrations of vanillic acid decreased steadily when compared to control that received no treatment except the vehicle (DMSO) (Figure 1). This decrease was very profound at the first 60 minutes and becomes steady at $140-180$ minutes. There was a time- dependent decrease in the cells of Staphylococcus aureus following exposure of vanillic acid, an indication of antibacterial activity of vanillic acid (Figure 2).

Vanillic acid increased $(p<0.05)$ the level of superoxide anion radical in the cell free extract of Staphylococcus aureus. The highest concentration $(0.1 \mathrm{mg} / \mathrm{mL})$ produced 
$82.32 \%, 78.11 \%$ and $78.03 \%$ increase in superoxide anion radical in Staphylococcus aureus when compared to the DMSO treated group (Figure 3). The activities of superoxide dismutase and catalase in the cell free extract of the bacterial cells treated with vanillic acid $(0.02-0.1$ $\mathrm{mg} / \mathrm{mL}$ ) increased significantly $(p<0.05)$ (Figures $4 \mathrm{a})$. Vanillic acid $(0.1 \mathrm{mg} / \mathrm{mL})$ produced $85.18 \%, 83.11 \%$ and $82.88 \%$ increase in the activity of superoxide dismutase in Staphylococcus aureus. Catalase activity in cell free extract of Staphylococcus aureus increased significantly $(p<0.05)$ following treatment with vanillic acid in a concentration dependent manner (Figure 4b). GSH level in cell free extract of Staphylococcus aureus decreased significantly $(p<0.05)$ following treatment with vanillic acid in concentration dependent manner (Figure 5a). Malondialdehyde, a biomarker of lipid peroxidation, increased significantly in the cell free extract of Staphylococcus aureus treated with vanillic acid (Figure 5b). There was significant increase in the absorbance and CFU/mL of Staphylococcus aureus incubated with 2,2'bipyridyl and vanillic acid (0.1 $\mathrm{mg} / \mathrm{mL}$ ) when compared with Staphylococcus aureus cells treated with only vanillic acids. This increase compared significantly with Staphylococcus aureus cells treated with only DMSO (Figure 6).

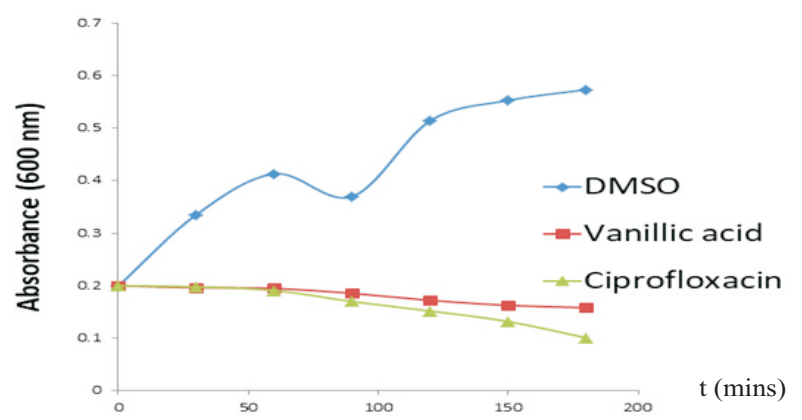

Figure 1: Optical density of Staphylococcus aureus cells incubated with vanillic acid. Values are mean \pm SEM of three determination and are statistically significant at $\mathrm{p}<$ 0.05

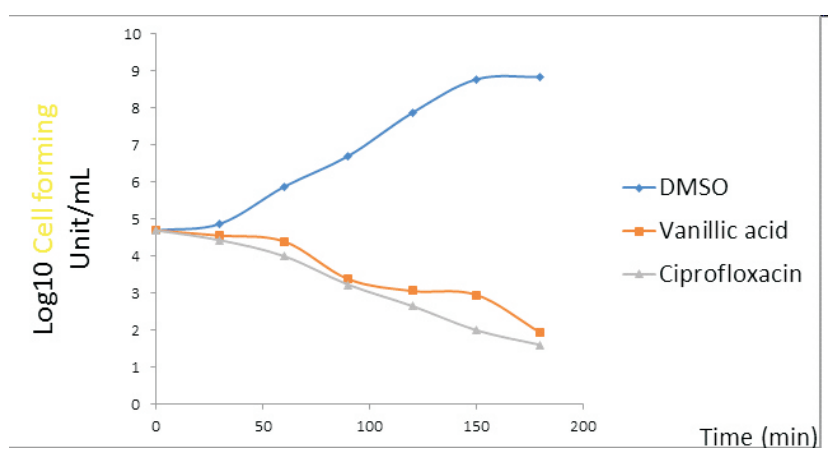

Figure 2: Cell forming units in Staphylococcus aureus cells incubated with vanillic acid. Values are mean \pm SEM of three determination and are statistically significant at $p<0.05$

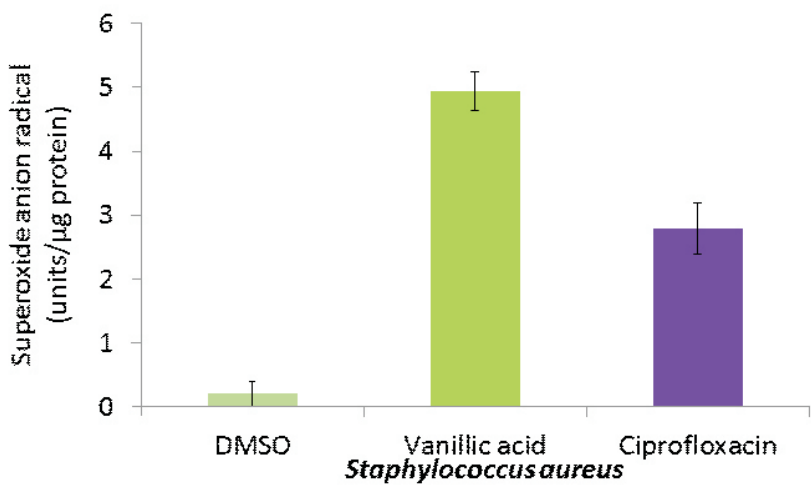

Figure 3: Level of superoxide anion radical in Staphylococcus aureus treated with vanillic acid $*=$ significant diff. $(p<0.05)$ vs DMSO
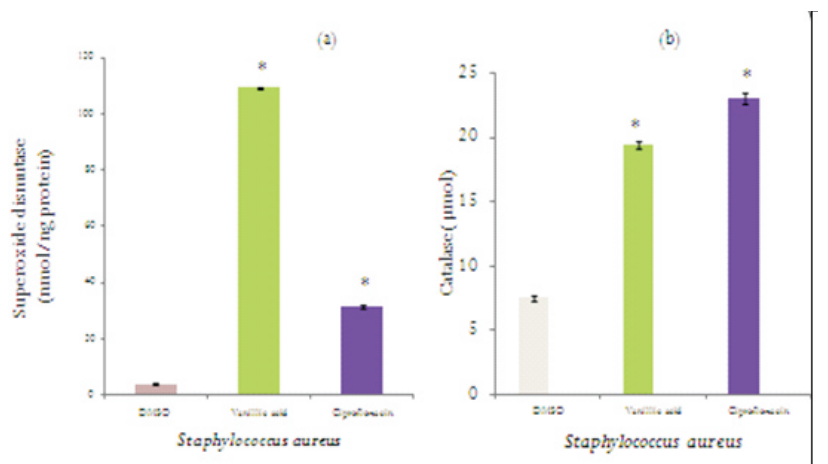

Figure 4: (a) Superoxide dismutase (b) Catalase activity in Staphylococcus aureus treated with vanillic acid. ${ }^{*}=$ significant diff. $(\mathrm{p}<0.05)$ vs DMSO

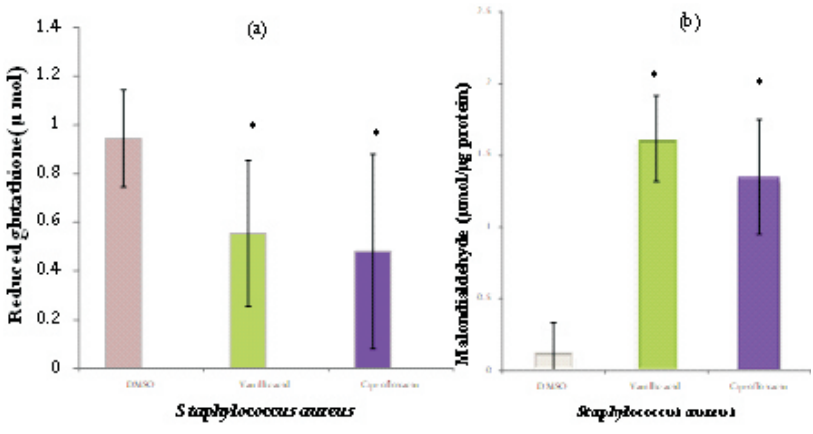

Figure 5: (a) Reduced glutathione (b) Malondialdehyde in Staphylococcus aureu treated with vanillic acid. ${ }^{*}=$ significant diff. $(p<0.05)$ vs DMSO

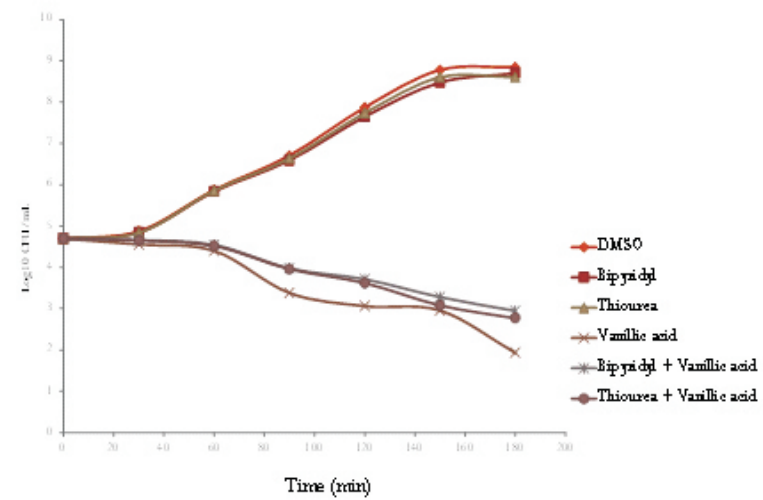

Figure 6: Involvement of hydroxyl radical in Staphylococcus aureus treated with vanillic acid 


\section{Discussion}

Antioxidants are considered important nutraceuticals on account of many health benefits $(15,16,17)$. Phenols are compounds with high antioxidant capacity, which may be responsible for their antitumor, antimicrobial, and cardiovascular preventive and antidegenerative activities among others $(18,19)$. Vanillic acid, a phenolic compound, is a naturally occurring active compound having antimicrobial, anti-inflammatory and antioxidant / anticancer properties (20).

The present study presents the possible involvement of oxidative stress in vanillic acid mediated bactericidal activity against Staphylococcus aureus. In the time kill assay, absorbance and CFU/mL of Staphylococcus aureus cells following exposure to vanillic acid significantly decrease in concentration and time dependent manner indicating the antibacterial activity of vanillic acid against Staphylococcus aureus. Thus, the decrease in CFU/mL of Staphylococcus aureus reported in this study supports the documented antibacterial activity of vanillic acid. Adefegha and Oboh (21) had reported the contribution of vanillic acid to lowering cellular oxidative stress and inhibit $\alpha$-amylase, $\alpha$-glucosidase, acetylcholinesterase and butylrycholinesterase activities. Merkl et al. (22) and Montes et al. (23) have also variously reported that the benzoic acid derivative such as vanillic acid presents antimicrobial properties against many bacterial and fungal strains.

In order to understand the involvement of reactive oxygen species in vanillic acid mediated bactericidal activity, the effect of this compound on superoxide anion radical was investigated. Previous studies have reported superoxide anion radical production as one of the mechanism by which ciprofloxacin, a quinolone, mediates antibacterial action. However, Polyphenols such as vanillic acid not only exhibit independent antibacterial effects, but also can suppress the antibiotic resistance of pathogen microorganisms or act synergistically in combination with conventional antimicrobial agents like (24).

Superoxide dismutases and catalase are antioxidant enzymes responsible for the detoxification of superoxide anion radical and hydrogen peroxide, which can be converted to a more potent antimicrobial agent, hydroxyl radical, in the presence of iron through Fenton reaction. Superoxide dismutases (SOD) are metalloenzymes that catalyze the dismutation of superoxide anion into oxygen
$\left(\mathrm{O}_{2}\right)$ and hydrogen peroxide $\left(\mathrm{H}_{2} \mathrm{O}_{2}\right)$ (25). This work revealed increased activities of superoxide dismutase and catalase in Staphylococcus aureus following exposure to vanillic acid, hence an enhanced superoxide and hydrogen peroxide production in Staphylococcus aureus cells. This could have occurred in an event to counteract/detoxify superoxide anion radical and hydrogen peroxide.

Oxidative stress in the cell free extract of $S$. aureus in this work relates to the significant decrease in the level of GSH in cell free extract of Staphylococcus aureus following treatment with vanillic acid. Superoxide dismutases (SOD), CAT and GSH-Px, together with GSH-S-transferase and GSH reductase, are easily induced by oxidative stress, and the activity levels of these enzymes have been used to quantify oxidative stress in cells (26). The level of malondialdehyde and fragmented DNA increased significantly in the cells of Staphylococcus aureus treated with vanillic acid when compared with the cells of Staphylococcus aureus treated with DMSO. The elevated level of malondialdehyde in the cell free extracts of Staphylococcus aureus treated with vanillic acid indicates peroxidation of lipid layer of cell membrane. Kalaycioglu et al. (27) reported that the interaction between reactive oxygen species (ROS) and cell membrane lipids lead to lipid peroxidation (oxidative reduction of lipids) and generation of a cytotoxic product, namely, malondialdehyde (MDA) which in turn leads to membrane disruption, myocardial cell damage, cardiac dysfunction and irreversible tissue injury. Hence, the observed elevated level of malondialdehyde concurs with the elevated levels of some endogenous antioxidant compounds i.e. superoxide dismutase, glutathione and catalase (as earlier observed in this work). The CFU of Staphylococcus aureus following exposure to vanillic acid increased significantly in the presence of 2,2 bipyridyl and Fchelator, when compared with treatment with only vanillic acid, suggesting the involvement of hydroxyl radical in the cell death.

\section{Conclusion}

Based on the findings from this study, it can be concluded that vanillic acid induced oxidative stress in Staphylococcus aureus as evident from the elevated levels of superoxide anion radical and antioxidant enzymes. However, the level of induced oxidative stress in $S$. aureus cells was higher when vanillic acid was mixed with 2, 2'-bipyridyl, an indication of synergy between vanillic acid and 2, 2'-bipyridyl. 


\section{Conflict of interest statement}

We declare that we have no conflict of interest.

\section{Source of funding}

This research received no specific grant from any funding agency in the public, commercial, or not-forprofit sectors.

\section{REFERENCES}

1. Itoh A, Isoda K, Kondoh M, Kawase M, Kobayashi M, Tamesada M, Yagi K. Hepatoprotective effect of syringic acid and vanillic acid on concanavalin a-induced liver injury. Biol. Pharm. Bull. 2009; 32(7). 1215-9.

2. Martin KR, Appel CL. Polyphenols as dietary supplements: a doubleedged sword. Nutr. Diet. Suppl. 2009; 2: 1-12.

3. Bravo L. Polyphenols: chemistry, dietary sources, metabolism, and nutritional significance. Nutrition reviews. 1998; 56(11): 317-33.

4. Stalikas CD. Extraction, separation, and detection methods for phenolic acids andflavonoids. J. Sep. Sci. 200; 30(18): 3268-95.

5. Lafay S, Gil-Izquierdo A. Bioavailability of phenolic acids. Phytochem. Rev. 2008; 7(2):301.

6. Robbins RJ. Phenolic acids in foods: an overview of analytical methodology. J. Agric. food Chem. 2003; 51(10): 2866-87.

7. Dhananjaya BL, Nataraju A, Gowda CR, Sharath BK, D'souza CJ. Vanillic acid as a novel specific inhibitor of snake venom 5'nucleotidase: a pharmacological tool in evaluating the role of the enzyme in snake envenomation. Biochemistry (moscow). 2009; 74(12): 1315-9.

8. Mol SD, Raja B. Therapeutic effects of vanillic acid on acetaminophen-induced hepatotoxicity in rats. Int. J. Pharm. Biol. Arch. 2010; 1(2):144-9.

9. Samoilova Z, Smirnova G, Muzyka N, Oktyabrsky O. Medicinal plant extracts variously modulate susceptibility of Escherichia coli to different antibiotics. Microbiol. Res. 2014; 169(4): 307-13.

10. Ajiboye TO, Mohammed AO, Bello SA, YusufII, Ibitoye OB, Muritala HF, Onajobi IB. Antibacterial activity of Syzygium aromaticum seed: Studies on oxidative stress biomarkers and membrane permeability. Microb. Pathog. 2016; 95:208-15.

11. Misra HP, Fridovich I. Superoxide dismutase:"positive" spectrophotometric assays. Anal. Biochem. 1977; 79(1-2): 553-60.

12. Trombino S, Cassano R, Bloise E, Muzzalupo R, Tavano L, Picci N. Synthesis and antioxidant activity evaluation of a novel cellulose hydrogel containing trans-ferulic acid. Carbohydr. polym. 2009;

\section{5(1): $184-8$}

13. Ellman GL. Issue sulfhydryl groups. Arch. Biochem. Biophys. 1959; 82(1):70-7.

14. Reilly CA, Aust SD. Measurement of lipid peroxidation. Chapter 2. In: Current protocols in toxicology. US: J. Wiley; 1999. $p$. 2.4.1-2.4.13.

15. Droge W. Free radicals in the physiological control of cell function. Physiol. Rev. 2002; 82(1):47-95.

16. Lee J, Koo N, Min DB. Reactive oxygen species, aging, and antioxidative nutraceuticals. Compr. Rev. Food Sci. Food Safety. 2004; 3(1):21-33.

17. Valko M, Leibfritz D, Moncol J, Cronin MT, Mazur M, Telser J. Free radicals and antioxidants in normal physiological functions and human disease. Int. J. Biochem. Cell Biol. 2007; 39(1):44-84.

18. Gañan M, Martínez-Rodríguez AJ, Carrascosa AV. Antimicrobial activity of phenolic compounds of wine against Campylobacter jejuni. Food Control. 2009; 20(8):739-42.

19. Marques FZ, Markus MA, Morris BJ. Resveratrol: cellular actions of a potent natural chemical that confers a diversity of health benefits. Int. J. Biochem. Cell Biol. 2009; 41(11):2125-8.

20. Natarajan K, Singh S, Burke TR, Grunberger D, Aggarwal BB. Caffeic acid phenethyl ester is a potent and specific inhibitor of activation of nuclear transcription factor NF-kappa B. Proc. Natl. Acad. Sci.. 1996; 93(17):9090-5.

21. Adefegha $S A$, Oboh $G$. Inhibition of key enzymes linked to type 2 diabetes and sodium nitroprusside-induced lipid peroxidation in rat pancreas by water extractable phytochemicals from some tropical spices. Pharm. Biol. 2012; 50(7):857-65.

22. Merkl R, HRádkoVá I, Filip V, ŠMIdRkal J. Antimicrobial and antioxidant properties of phenolic acids alkyl esters. Czech J. Food Sci. 2010; 28(4):275-9.

23. Montes R, Perez A, Medeiros C, Araújo M, Lima E, Scotti M, Sousa D. Synthesis, antifungal evaluation and in silico study of $n-(4-$ halobenzyl) amides. Molecules. 2016; 21(12):1716.

24. Nychas GJ. Natural antimicrobials from plants. InNew methods of food preservation Springer, Boston, MA. 1995. pp. 58-89.

25. Fridovich I. Superoxide dismutases. Adv. Enzymol. Relat. Areas. Mol. Biol. 1986; 58(6):61-97.

26. Van der Oost R, Beyer J, Vermeulen NP. Fish bioaccumulation and biomarkers in environmental risk assessment: a review. Environ Toxicol. Pharmacol. 2003; 13(2):57-149.

27. Kalaycioglu S, Sinci V, Imren Y. Metoprolol prevents ischemiareperfusion injury by reducing lipid peroxidation. Japanese Circ. J. 1999; 63(9):718-21. 